\title{
Belonging to Place: Interpretative Phenomenological Analysis of Incremental Housing
}

\author{
Goran Ivo Marinovic ${ }^{1}$ \\ Recibido: 14-10-2020 | in it last version: 30-12-2021
}

Abstract

\begin{abstract}
Incremental housing, supported by governmental funding, signifies a solution for lowincome households, allowing them to self-manage the process of customising unfinished units. This article uses interpretative phenomenological analysis to examine the households' belonging to their incremental house. The aim is to argue that there is room for theorising incremental housing, which adds insight to the importance of gathering in a place without oversimplifying the diversity of building and living responsibilities held by the residents. The author uses Martin Heidegger's idea of dwelling to examine the entwined notion of building and inhabiting an incremental house. The underlying reason behind using Heidegger's work is his interpretation of a dwelling, which he sees as a continuing process of building a house. The hypothesis holds that households' efforts to complete the unfinished house cultivates the sense of gathering family members for increasing their sense of belonging to the place. This belonging is understood in relationship with the occupants' routine, such as the physical and social organisation of the building process, which transcends social hindrance present in low-income neighbourhoods.
\end{abstract}

Keywords: Martin Heidegger; dwelling; elemental; Villa Verde housing project; customisation

Citation

Marinovich, G.I. (2021). Belonging to Place: Interpretative Phenomenological Analysis of Incremental Housing. ACE: Architecture, City and Environment, 16(46), 9706. DOI http://dx.doi.org/10.5821/ace.16.46.9706

\section{Pertenencia al lugar: análisis fenomenológico interpretativo de la vivienda incremental}

Resumen

\begin{abstract}
La vivienda incremental, respaldada por fondos gubernamentales, significa una solución para los hogares de bajos ingresos, que les permite autogestionar el proceso de personalización de unidades sin terminar. Este artículo utiliza un análisis fenomenológico interpretativo para examinar la pertenencia de los hogares a su casa incremental. Su objetivo es argumentar que hay espacio para teorizar la vivienda incremental, lo que da una idea de la importancia de reunirse en un lugar, sin simplificar demasiado la diversidad de responsabilidades de construcción y vivienda de los residentes. El autor utiliza la idea de vivienda de Martin Heidegger para examinar la noción entrelazada de construir y habitar una casa incremental. La razón subyacente para utilizar el trabajo de Heidegger es su interpretación de una vivienda, que él ve como un proceso continuo de construcción de una casa. La hipótesis sostiene que, los esfuerzos de los hogares para completar la casa sin terminar, cultiva el sentido de reunión de los miembros de la familia, para aumentar su sentido de pertenencia al lugar. Esta pertenencia se entiende en relación con la rutina de los ocupantes, como la organización física y social del proceso de construcción, que trasciende el impedimento social presente en los barrios de bajos ingresos.
\end{abstract}

Palabras clave: Martin Heidegger; vivienda; elemental; proyecto de vivienda Villa Verde; personalización

${ }^{1}$ Lecturer, Michael Graves College of Architecture and Design, Wenzhou-Kean University (ORCID: 0000-0003-46444283). Contact e-mail: gomarink@yahoo.com

ACE, 16 (4.6) CC BY-ND 3.0 ES | UPC Barcelona, España | Belonging to Place: Interpretative Phenomenological Analysis of Incremental Housing. DOI: http://dx.doi.org/10.1080/ace.16.46.9706 


\section{Introduction}

According to Hannu Ruonavaara, it is not necessary to theorise in architecture; therefore, the theory about housing is neither possible nor desirable. However, theory in architecture is indispensable because architects should "apply theoretical resources developed in established disciplines and research fields in theorising housing-related topics” (Ruonavaara, 2018, p.181). From this point of view, this research offers a vision of belonging to a place by constructing houses while occupying them. Drawing on the idea of dwelling of Martin Heidegger, the author examines the entwined notion of building and inhabiting an incremental house. The underlying reason behind using Heidegger's work is his interpretation of a home as a "site of emergence, something which is produced, performed and in a state of always becoming” (Cook et al. 2013, p.294).

There is much that Husserl, Heidegger (Overgaard, 2004), and Merleau-Ponty (Heinämaa, 2015) agree on when it comes to the concepts such as world and being. All three conceive of the world as a phenomenon-the world that is disclosed in experience-and maintain that this world is nothing other than the world itself (Zahavi, 2018). They all used Kantian language when characterising their philosophical projects, such as transcendental phenomenology (Husserl), fundamental ontology or existential analytic of Dasein (Heidegger), and a phenomenology of the transcendental field (MerleauPonty) (Gardner \& Grist, 2015). Heidegger's phenomenology is mostly based on the concept of "Dasein" which is influenced by a link with time and history (Erciyes, 2019). He defines Dasein as "an entity which in its very being comports itself understanding toward that being” (Heidegger, 1994, p.78). The essence of Dasein cannot be separated from the living world and lies in its existence (Heidegger, 1962). From this context of lived world, the author examined the low-income households' experience of customising houses. For Heidegger, the processes of constructing and inhabiting houses are inseparable, which is present in incremental housing as "a gradual step-by-step process whereby building components are appended by owner-builders as funding, time, or materials become available" (Moullier \& Krimgold, 2015, p.15). This juxtaposition of philosophical sources dialogue and incremental building process provides insights to inhabitants' perception of the units that is revealed through the emotional lens of each individual. The low-income families follow self-building practice to complete the unfinished houses. This process serves as a lesson for better living, which is interpreted in this article as a platform for dwelling and belonging.

Incremental housing refers to solutions where government has developed programmes of "assistance for owner-builders" (Harris, 1999, p.293). This housing solution applies to situations where the government created an environment favourable to the owner-building of houses, also defined as "nuclear families with state support" (Duncan \& Rowe, 1993, p.1332). It represents an open-ended housing platform, which allows people to transform their habitable space through time (Noorloos et al. 2019). Incremental housing is a strategy based on a progressive system, where construction is incomplete but in conditions of habitability (Adler \& Vera, 2018). This approach of 'build-as-you-go' depends on micro-loans and self-building process. It is a good way to include the less privileged in the banking system, by providing land tenure and promoting entrepreneurialism at a small scale (Boano \& Perucich, 2016). The idea of incremental housing is concurring with John Turner's and Robert Fichter's argument of housing as a process which is never-ending for the less privileged groups in society (1972). Turner captured different growth patterns of housing that manifest changes in families' size and life styles (2018). The outcome of these solutions is not an aesthetically pleasing form, but rather lessons in better living. Incremental construction offers low-income households a means of affordable homeownership otherwise unavailable to them. A rule-of-thumb is to consider a unit as an incremental house if the household is significantly involved in the construction process (Duncan \& Rowe, 1993). Margarita Greene and Eduardo Rojas described incremental housing as a programme fostered to support "the gradual process of construction, extension, and upgrading of dwellings that

ACE, 16 (4.6) CC BY-ND 3.0 ES | UPC Barcelona, España | Belonging to Place: Interpretative Phenomenological Analysis of Incremental Housing. DOI: http://dx.doi.org/10.1080/ace.16.46.9706 
is undertaken by many families" (2008, p.91). This article focuses on ability of families to concurrently cope with building process and inhabiting the delivered house.

Incremental housing has two phases of development, the first phase provides households with the starting house and the next one involves households' investment in the customisation of the delivered unit. The incremental construction is a lasting process of inhabitation of unfinished units that prompts households' belonging to the place. The author associates this households' belonging with Heidegger's two different components of dwelling: gathering and creation of an environment in a locale where everything finds its proper place and a system of distribution, in which the things gathered stand out in the gathering as different from one another (Bjering, 2017).

In his seminal text "Building, Dwelling, Thinking", originally published as a lecture to the Darmstadt Symposium on "Man and Space" in August 1951, which a part of a group of three lectures - the other two being "The Thing" and "Poetically Man Dwells" - the philosopher states that we build (a building) in order to dwell (in said building) (Bjering, 2017). With this in view, "to build is already to dwell, and dwelling is the basic character of human being -it is man's Being" (Heidegger, 1993, p.350). The words building and dwelling, allow the philosopher to emphasise inhabitation and experience over the design and construction process. He explains the relationship between building, German: bauen, and dwelling, German: wohnen (Heidegger, 1971a). For him, bauen reflects "coming to light of things that grow in time from the earth skyward," and wohnen "means to reside or stay, to dwell at peace, to be content" (Heidegger, 2008, p.345). The philosopher suggested that these terms share the same root in the Old High German word buan means to dwell, and that building and dwelling were previously understood as the same activity, to cultivate, Latin colere (Heidegger, 1971b). In this context, family members inhabiting an incremental house have to be in a state of belonging that is defined as permanent staying in the place and the relationship between community members that allows unity and cooperation (Barbaza, 2003). To inhabit the delivered house is never a matter of self-appropriation of the place; instead, it directs the occupants towards the relational understanding of the living environment.

The article aims to present incremental housing as a worthy subject for theory-making where the author elucidates incremental houses by using phenomenological lenses and focusing on low-income families' construction process during inhabitation of the unfinished houses. The hypothesis holds that households' efforts to complete the unfinished house cultivates the sense of gathering family members for increasing their sense of belonging to the place. From this point of view, incremental housing represents the unfinished vessel that allows different living conditions for the occupants during the completion of the house. Following Mark Okrent's reading of Heidegger as a pragmatist, dwelling is over against "the technocratic and rational process that architecture has become" (1991, p.3), which corresponds with Hill's representation as "a barrier between peoples' everyday dwelling and its organic manifestation into a built environment" (Hill, 2008, p.116). Against this background, this article examines the importance of the run-of-the-mill dwelling, often heeded by architects, by giving importance to self-build process in incremental housing.

The author intersects social and organisational power relations of households by using an interpretative phenomenological analysis of belonging to a place. This qualitative research method offers insights into how a given low-income family makes sense of inhabiting unfinished houses. The presence of linear routes through data analysis misses the hermeneutic phenomenological point of interpretative phenomenological analysis, thus lacking in rigour and credibility (Engward, \& Goldspink, 2020). Therefore, the objective is to theorise around a concept (sense of belonging) that is eminently phenomenological, but that needs to be tested in the field to assess its existence. With this in view, to support and substantiate the theoretical framework of the article, the author interviewed one household from Villa Verde incremental housing project constructed in 2016 in Constitución, Chile.

ACE, 16 (4.6) CC BY-ND 3.0 ES | UPC Barcelona, España | Belonging to Place: Interpretative Phenomenological Analysis of Incremental Housing. DOI: http://dx.doi.org/10.1080/ace.16.46.9706 
Lessons from the conversation with the household frame human interaction with the world and argue for "more reflective and deliberate" way of living (Sharr, 2007).

In addition to the introduction, the article contains three more sections which examine low-income families' belonging to incremental housing. The first section presents the interpretative phenomenological analysis of delivered houses based on the notion of gathering present in the void of the house. The author introduces emptiness of a house that invited low-income families to cultivate and nurture their relationships with household members and the neighbours, which is of importance for achieving closeness. The second part introduces the Villa Verde housing project, while the third section focuses on households' creation of meaning, which is done in accordance with individual human imaginations, through building and dwelling. The conclusion addresses the three main points of the article and points limitations of this study while offering an argument for the importance of theorising incremental housing.

\section{Belonging to customised houses}

The process of building through inhabiting a house offers the occupants a tool for understanding their furniture arrangement, size of rooms, and functionality of the house. This interpretation of the place becomes a physical demarcation for family members, embodied in their unity to cope with different living conditions. The unity relates to belonging to a place that generates a setting for secure and familiar living environment based on reliance to the others. According to this view, "we are constantly placing ourselves in a specific place and time and that mediation of place enables our relation to the world which is an a priori requisite of our existence" (Unwin, 2009, p.20). Unwin argues that we are constantly situating ourselves in relation to things, to people, to the forces of nature. Against this background, Heidegger analyses the term "belonging together" as a difference between the understanding of such belonging in a way that emphasizes the belonging or the together (Heidegger, 1957, p.25). Being situated in a place enables humans to belong to the community with limited participation or to gather in order to unify their actions based on attentiveness and responsiveness. The latter category relates to staying together for examining families' closeness embedded by personal relationships from which derives the importance of customising houses as relational comprehension of incremental housing.

Heidegger states that the original meaning of gathering is not "thinking, understanding, and reason", but "the relation of one thing to another" (2000, p.132). Arguing against inhabitants' complacency by occupying dwelling as a passive user, the philosopher advocates for a lasting process of settling in the place that is the substance of dwelling. The approach to building directs us to relationships as priorities that involves acknowledgement of human closeness. This manner overcomes organisational way of building that draws attention to professional know-how and hired labour for construction (Marinovic, 2020). The relational model of housing introduces inclusive construction process by involving family members, kin, and friends whose participation is of paramount importance. This notion of concurrent building and dwelling invites families to go beyond technical notions of incremental housing such as "well planned", "a good half of the house", "easy to customise", "affordable and attractive" (Aravena \& lacobelli, 2016). The relational approach of subsequent building whilst inhabiting unfinished houses creates stronger households' relationships with the locality based on help from their kin and friends. These self-built housing schemes foist households to have the double task of physically building their houses while, at the same time, settling their families within existing or newly formed communities (Boccagni \& Brighenti, 2017). Families establish an ongoing relationship with their neighbours at a variety of scales, taking place over months, years and lives. In this framework, we can understand the importance of the occupants' routine, such as the physical

ACE, 16 (46) CC BY-ND 3.0 ES | UPC Barcelona, España | Belonging to Place: Interpretative Phenomenological Analysis of Incremental Housing. DOI: http://dx.doi.org/10.1080/ace.16.46.9706 
and social organisation for customising the delivered house. All recorded building techniques in incremental housing projects are shared among the community members; hence to customise a house by following the relational approach of building, families need to establish a living routine.

Delivered house is an unfinished house whose completion depends on unpaid labour provided by the kin and friends of low-income families. It is delivered with only the most rudimentary features and is upgraded later at a pace based on the financial capacities of the family. The house, as the first construction phase of the incremental process, denotes the core of the incremental programme (Greene, 2004). The idea of delivered house originates from "the self-built core house" or "sanitary unit system" for upgrading informal settlements in urban areas (Pandelaki \& Shiozaki, 2010). After the First World War, this housing solution was first developed in Europe and the Soviet Union as a pragmatic, untheorized and urgent response to a severe housing shortage, and later in the United States (Harris, 1999). Taking into account households' needs to incrementally invest in their homes, the author embraces the definition of the delivered house as a housing frame with a void left to be completed in time. For low-income households the unfinished house is an opportunity to open new uses and possibilities (Perucich \& Boano, 2016).

To create a completely functional unit, a family ought to manage building over the long term and means "insertion in a community of producers where involvement in self-provided projects is an accepted part of life" (Harms, 1982, p.18). This self-building depends on a social policy that encourages homeownership and households' participation in using the subsidy as a leg up into the private housing market so that residents can benefit from the capital gains (O'Brien, Carrasco, \& Dovey, 2020). It takes various dwelling forms depending on the opportunities and challenges of the progressive construction process (Adeyeni, 2015). The progressive building is also seen as the process by which low-income households make incremental investments in housing as their income permits (Hasan, 2000).

Ostrom has argued that self-organisation often works well (1990), over and above there is an incentive for residents to invest in the house and to expand it with high-quality additions (Zilliacus, 2016). This concern echoes the increase of participation of low-income households following an incremental housing framework (Wainer et al. 2016). Pojani stresses that flexibility in the spontaneous development of housing and settlements should encompass safety, security and ensure the continuation of urban functions (2019). Customisation of houses rely on long-term preparation, which includes families' collecting and storing construction materials, arranging the required labour, and often negotiating with the neighbours (Kamalipour, 2020).

\section{Villa Verde District}

An example of incremental housing is a settlement Villa Verde (figure 1), completed in 2016 in Chile with 484 houses (Valencia, 2016). A Chilean resource company, Arauco, commissioned Elemental architectural office to design a new estate to house timber workers and families near the small city of Constitución in Maule Region. Elemental developed this neighbourhood claiming it is a more complex design with higher standards enabled by both private and government subsidies (Aravena \& lacobelli, 2016). The planning and design process of Villa Verde was assisted by the Supportive Housing Fund (Spanish: el Fondo Solidario de Vivienda: FSV) offered by the Ministry of Housing and Urban Development (MINVU) of the government of the Republic of Chile (Marinovic, 2018; Arauco, 2013). This funding program enabled low-income families to purchase and construct a residential unit without mortgages in urban, semi-urban, and rural areas of Chile.

ACE, 16 (4.6) CC BY-ND 3.0 ES | UPC Barcelona, España | Belonging to Place: Interpretative Phenomenological Analysis 


\section{ACE Architecture, City and Environment}

The major strengths of FSV support are greater flexibility and wider choices, better social integration, focus on members of the community who are in urgent need for housing, effort award (additional options for saving), and higher-quality residence units and better quality of life (The Ministry of Housing and Urban Development, 2020).

Figure 1. Urban Plan of Valla Verde neighbourhood with location of the participant's house, and view of the central part of the neighbourhood, 2015, Constitución, Chile

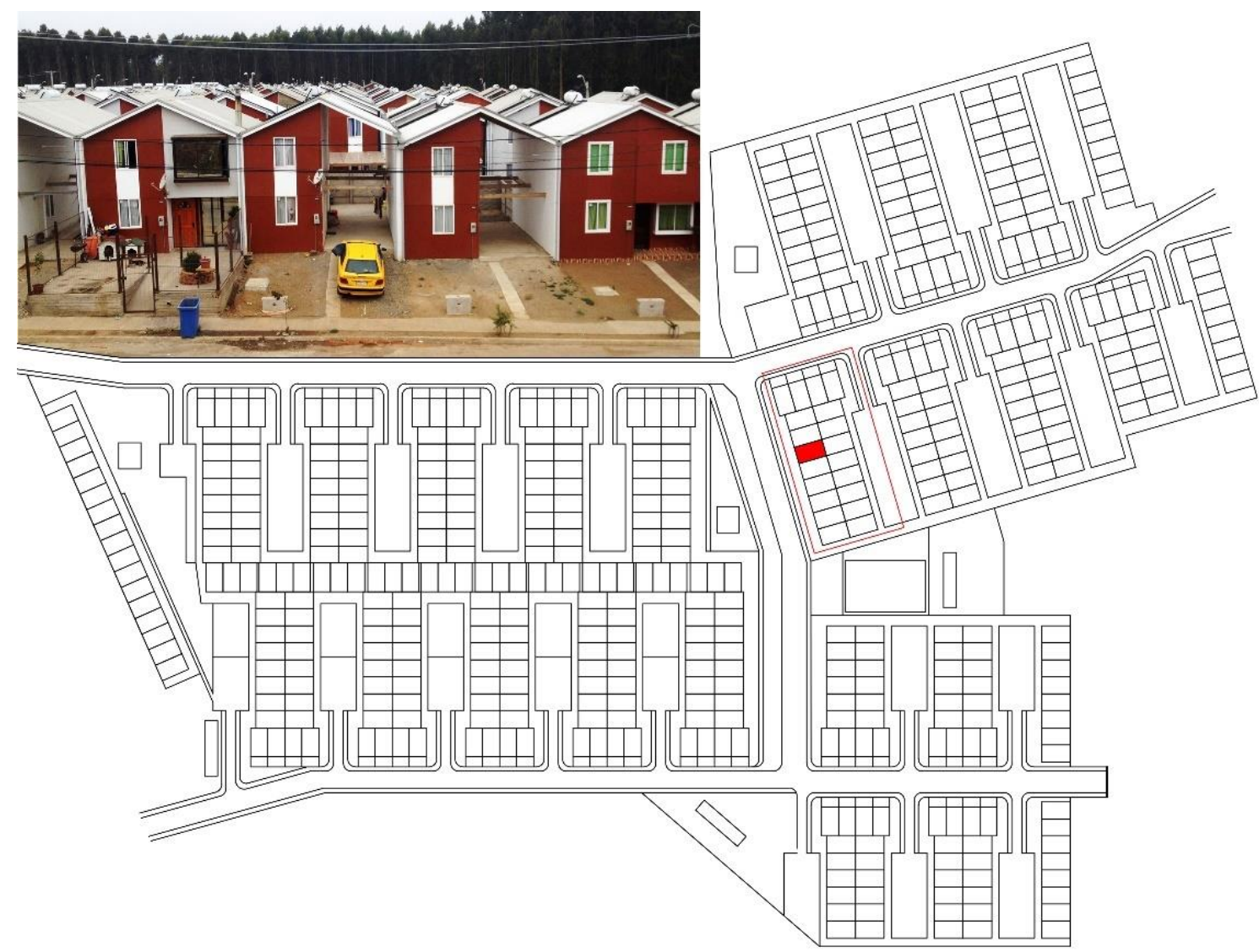

Source: Elaborated by author.

Villa Verde contains two types of units; the first is initially designed as a 56.44 square meter unit which can be extended into the total of 64.90 square meter (type A), and the second is a 56.88 square meter unit that can expand into 85.10 square meter (type B) (figure 2). $87 \%$ of all houses are type A and they have become the dominant unit of the project, while few type B houses have less capacity for customisation since they were initially intended as houses for the elderly (O'Brien, Carrasco, \& Dovey, 2020). The initial phase of the house occupies a relatively small part of the land, with a standard unit of $3.15 \mathrm{~m}$ in width and $7 \mathrm{~m}$ in depth.

The initial ground plan with the footprint of 22.05 square meter contains a hallway with a stairway, a bathroom, a kitchen, and a dining room (O'Brien \& Carrasco, 2021). With this in view, the delivered house as an unfinished unit encourages inhabitants to create meaning of the spatial void. For supporting the argument of belonging to a place, the author interviewed one family that inhabits type A house located in the central area of the neighbourhood (Figure 1). 
Figure 2. Valla Verde
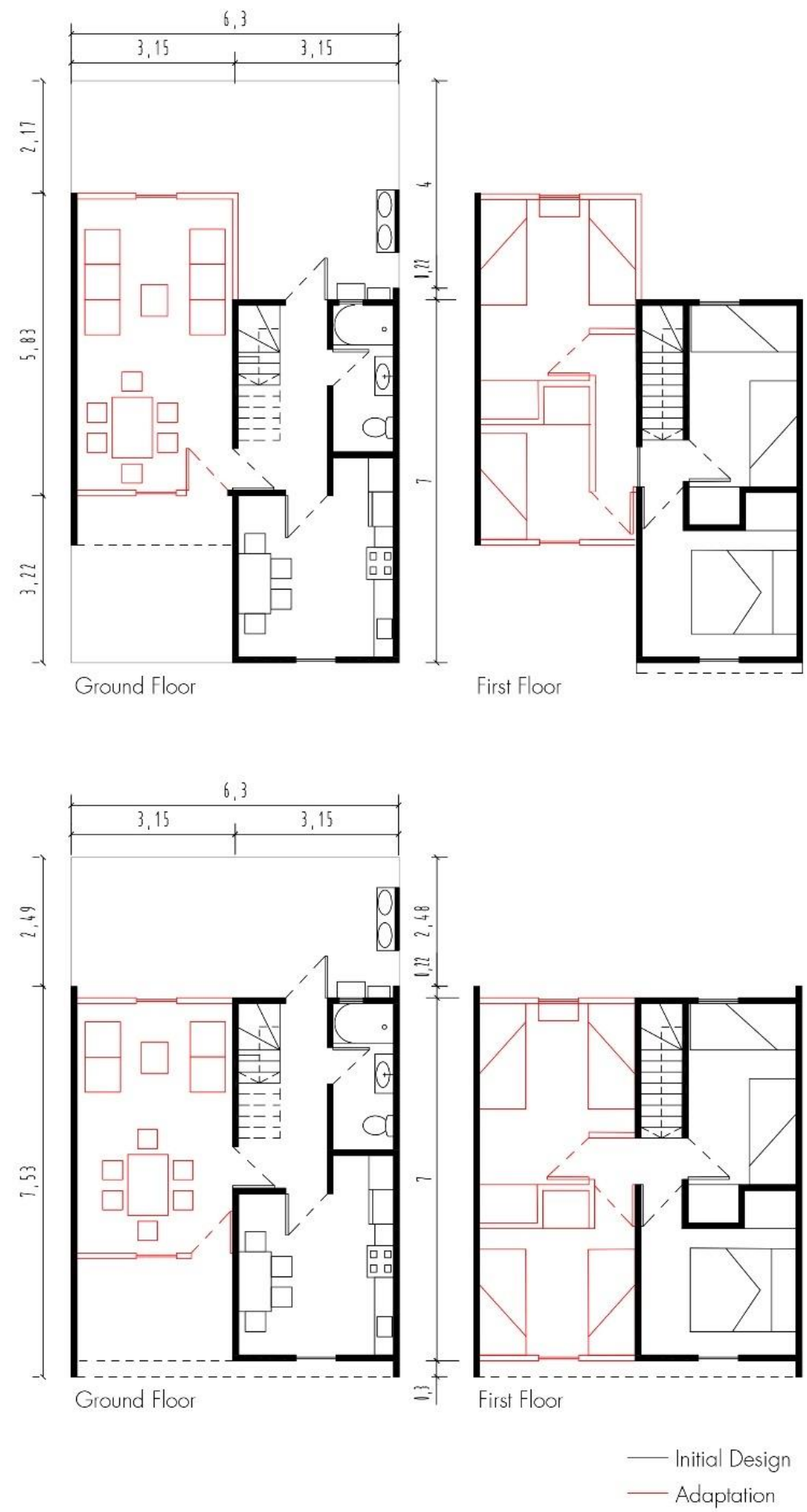

Source: Ellaborated by author.

Note: type A (up) and type B (down) houses, ground floor and first floor after the extension by residents, Elemental Architects, 2015, Constitución, Chile.

ACE, 16 (46) CC BY-ND 3.0 ES | UPC Barcelona, España | Belonging to Place: Interpretative Phenomenological Analysis of Incremental Housing. DOI: http://dx.doi.org/10.1080/ace.16.46.9706 


\section{Creating meaning of the spatial void}

During the interview, apart from their satisfaction with the house, the participant declared the need to improve the privacy regarding the neighbours and rooms in the house. The need for privacy (especially for teenagers) is more difficult to satisfy unless the spatial configuration of the house is intervened, either by enlarging the house or by subdividing rooms, a difficult task given their limited dimensions (Mora et al. 2020). With this in view, this family extended the house on the ground floor by building the living room and by adding a sleeping room on the second floor. Although satisfied with the personalised part of the house, they stated the need to improve thermal comfort. "The house is big enough for us, but we need to work on the finishes to make it warmer" (Female, 40; Interview, November. 11, 2015). In opposition to different challenges of customising houses, such as constructing larger windows, binding interior walls, finishing interior surfaces (with ceramic tiles, plaster and painting it with bright colours) and placing fences in yards, families' belonging to the delivered houses is linked to their different interpretation of the spatial void. The holistic and dynamic process of transformation of the incremental units might be understood as a process of constructing a place, defined as "any environmental locus that gathers human experiences, actions and meanings spatially and temporally” (Seamon, 2018, p.48).

An unfinished house invites occupants to get together (German: Versammeln) within constructed walls. For Heidegger, the house is void in-between walls that have the potential to embody, through its existence and its use, the human engagement with it. An example of this gathering power is presented in a jug whose emptiness exemplify tactile, cognitive and sociological familiarity of things (Sharr, 2007). This depiction relates to Heidegger's semantic factor "in the old usage of the word thing, namely gathering, that relates to the nature of the jug" (Heidegger, 1971c, p.166). By gathering around a jug people establish a meaningful relationship between themselves and augment the attachment to the place they occupy. The void of the vessel enables people to be bound up intimately with one another by using the emptiness for making meaning in different life situations. The Eastern Philosopher Lao Tzu emphasised: "With a wall all around / A clay bowl is moulded; / But the use of the bowl / Will depend on the part / Of the bowl that is void" (1955, p.63). Apart from enclosing the space, the walls serve to capture diverse possibilities of usage that open possibilities for a user's meaningful existence. The wall encloses "the environment where the closest social relations occur, either with family or neighbours, it is the threshold between the public and the private" (Mària \& Fuertes, 2020, p.16). With this in view, dwellers establish meaningful existence by embracing the emptiness of the vessel through customisation of their walls. Interpreting Lao Tzu's text, Blankney noted that the advantage of a jug "lies in its walls, but its use depends on its emptiness" (Lao Tzu, 1955).

The strength of emptiness and its power of assemblage is given poignant expression in a painting by Vincent van Gogh (Figure 3). Known for producing depictions of everyday objects making them surrogates for human presence, van Gogh in "Still life with three beer mugs" (1884) investigates people's relationship to each other embodied as a part of collective. These three mugs represent the human condition of staying together in relation to their space in-between. The painting is a detailed, almost tactile description of the essential character and evocative mood of a table with three jugs. Beyond the painting's realistic depiction and character, the scene contains relational elements: the darkness of background signifying placeness and importance of interhuman activities; the shadow linking the three objects makes the scene about users' interdependence; empty (right), presumed half-empty (middle) and full or not open jug (left) all suggest a different level of encroaching emptiness between them. The wall of a mugs flutters toward the other two overcoming their physical limits and connects their inner void with spaces between objects. The walls of mugs restrain their inter void, however the object is not limited by it. Walls of three objects are intertwined and their

ACE, 16 (46) CC BY-ND 3.0 ES | UPC Barcelona, España | Belonging to Place: Interpretative Phenomenological Analysis 8 of Incremental Housing. DOI: http://dx.doi.org/10.1080/ace.16.46.9706 
inner emptiness is projected in space between them. The unity of externa and internal voids incorporates making meaning of life situations and a correspondingly different analysis of voids is preserved forever in a still life presented by the painter. These relational aspects present in the void of the vessel and spaces in-between are also present in customisation of incremental housing.

As an open-ended unit, increment housing necessitates a process of households' making meaning by spatial adaptation of houses that allows them to position themselves as a part of collective. Selfbuilding process unites family members and opens possibilities for collaboration between the neighbours. The void of a unit celebrates collective engagement for inhabiting and adjusting the delivered house, and it lends itself to diversity in the outward appearance of housing. The emptiness of the incremental house is enveloped with different materials as a result of the dwellers' efforts to turn the house's structural frame into a liveable home. With this in view, the participant from Villa Verde explained that to catch light, they need agreement from the neighbour to orient the roof window toward the sun. Even though this situation is the consequence of an architect's decision to use the most economic urban planning for the orientation of houses, it forces members to sustain community bonds among themselves. Although it took two years for the interviewed family to adapt their house, its emptiness directs families to achieve the essential needs for meaningful living. Satisfaction of the essential needs is families' motivation for achieving belonging to the place linked with spatial and formal simplicity of a building.

Figure 3. Vincent van Gogh, 1884, Still life with three beer mugs

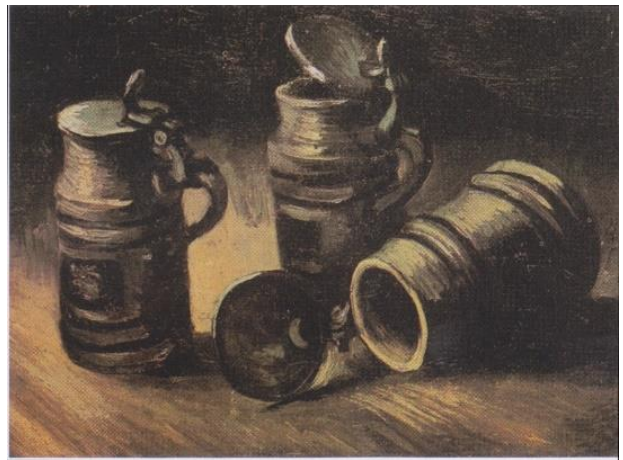

Source: Faille, Jacob Baart de la, 1970, The Works of Vincent van Gogh. His Paintings and Drawings, Amsterdam: J.M. Meulenhoff, p.49.

\section{Conclusion}

Whereas architects position incremental housing outside the major academic debates, this article presented it as a worthy subject for theory-making. The author argued that there is a room for a theory of incremental housing that adds insight to the importance of gathering in a place without oversimplifying the diversity of construction process and social responsibilities held by the residents. For achieving this objective, the interpretative phenomenological analysis is used for examining families' belonging to incremental houses. Following Heidegger's ideas of dwelling which invites occupants to the lasting process of building, this article focused on households' customisation of houses that is addressed as a measurement that goes beyond the architectural conceptualisation of space. This measurement triggers their imagination and projection for the future living environment based on the customisation of houses.

ACE, 16 (4.6) CC BY-ND 3.0 ES | UPC Barcelona, España | Belonging to Place: Interpretative Phenomenological Analysis of Incremental Housing. DOI: http://dx.doi.org/10.1080/ace.16.46.9706 
Drawing on the idea of belonging to place, this article demonstrated the need for simultaneous theorising low-income families' customisation and inhabitation of incremental housing. The author argued for the importance of gathering family members for a personal alignment to others with respect to temporal and spatial identification of their home. The three lessons from examining the aspect of households' living and building incremental houses are embedded in the following terms:

1. the belonging that represents the unity of the families' responsibilities during living and building their home. This article demonstrated the importance of occupants' attachment to the construction process that allows the unity of their actions. To inhabit the delivered house is never a matter of the self-appropriation of the place, instead, it directs the family members towards the relational understanding of their living environment. Regarding their communal bonds, the house both gathers and is itself gathered by cultivating interdependency between the household members. This nature of the gathering, such as belonging to a place, unifies members of a community and differentiates social responsibilities that derive from the occupants' constant positioning of themselves in relation to things, people, and the forces of nature. This process of gathering directs them to create domesticity and strengthen communal responsibility rather than to be isolated and paralysed by conformity.

2. the void of the incremental house provides the platform for going beyond technical notions of dwelling, such as well planned, a good half of the house, easy to customise, affordable, and attractive. This emptiness of the house calls for human closeness attained by inhabitants' care for others during the process of customisation. The void of the vessel empowers households to be bound in the place and to strengthen the relationship with one another. It opens room for different interpretations and serves to capture diverse possibilities of usage. Occupants establish meaningful existence by embracing the emptiness of a house.

3. the occupants' routine that motivates families' commitment to customising houses. The occupants' everyday activities and customisation of houses were presented as a dynamic process embedded in activities that are constantly being worked out. Households' lives were filtered in the way they extended the house, organised the rooms, placed the furniture, and gathered in the living areas. These activities enable them to be part of the household as well as the community. In the old sense of ethos, denoting sharing values, households' efforts to inhabit the delivered house is a platform for being part of kindred souls.

These three lessons overlapped the argument for the unification of occupants' experiences of houses that enabled them to be gathered in a home, and the unity was examined through families' relation of attentiveness and responsiveness that directed occupants to turn their attention to the face that is immediately before them instead of directing it to the surrounding. This engagement demonstrated the occupants' tendency to view incremental houses as a relational concept. The interpretation was presented as a physical demarcation of the location and the invitation for overcoming domesticity and romantic complacency. It is worth mentioning that the author used phenomenological analysis and did not consider other theoretical interpretation of incremental construction process. Furthermore, the article did not involve other case studies of incremental housing, encompass importance of micro loans, or examined the role of policy makers. With this in view, the tasks that the author has set are too ambitious to do more than provide initial thoughts on a theorised incremental housing. Others will have to build further, developing research that goes beyond the architectural conceptualisation of space and examines households' imagination and projection of the customised house.

ACE, 16 (4.6) CC BY-ND 3.0 ES | UPC Barcelona, España | Belonging to Place: Interpretative Phenomenological Analysis of Incremental Housing. DOI: http://dx.doi.org/10.1080/ace.16.46.9706 


\section{Acknowledgements}

I am thankful to Dr Fernando Saucedo Lastra for reading the first draft of this manuscript and providing insights for improvements.

Disclosure statement: The author declares that he has no significant competing financial, professional, or personal interests that might have influenced the performance or presentation of the work described in this manuscript.

\section{Bibliography}

Adeyeni, G.O. (2015). A study of incremental housing development in Ibadan municipality, Nigeria (Doctoral thesis). Urban and Regional Planning, Obafemi Awolowo University lle-Ife, Nigeria.

Adler, V. \& Vera, F. (2018). Vivienda ¿Qué viene? De pensar la unidad a construir la ciudad. Washington, D.C. United States: Inter-American Development Bank.

Arauco (2013). Manual de Habitabilidad. Proyecto Barrio Villa Verde Constitucion. Santiago, Chile: Arauco.

Aravena, A. \& lacobelli, A. (2016). Elemental: Incremental Housing and Participatory Design Manual. Stuttgart, Germany: Hatje Cantz Verlag.

Barbaza, R. (2003). Heidegger and a New Possibility of Dwelling. Bern, Switzerland: Peter Lang. Bjering, J. (2017). Borrowing, dwelling, owing. Home Cultures, 14(1), 95-111. DOI: https://doi.org/10.1080/17406315.2017.1319598

Boano, C. \& Perucich, F.V. (2016). Half-happy architecture. Viceversa, 4, 58-81.

Boccagni, P. \& Brighenti, A. M. (2017). Immigrants and home in the making: Thresholds of domesticity, commonality and publicness. Journal of Housing and the Built Environment, 32, 1-11. DOI: https://doi.org/10.1007/s10901-015-9487-9

Cook, N., Smith, S. J. \& Searle, B. A. (2013). Debted Objects: Homemaking in an Era of Mortgage-Enabled Consumption. Housing, Theory, and Society, 30(3), 293-311. DOI: https://doi.org/10.1080/14036096.2013.767280

Duncan, S. \& Rowe, A. (1993). Self-provided Housing: The First World's Hidden Housing Arm. Urban Studies, 30(8), 1331-1354. DOI: https://doi.org/10.1080/00420989320081291

Engward, H. \& Goldspink, S. (2020). Lodgers in the house: living with the data in interpretive phenomenological analysis research. Reflective Practice, 21(1), 41-53. DOI: https://doi.org/10.1080/14623943.2019.1708305

Erciyes, E. (Jan, 2019). Three Pillars of Phenomenology: Husserl, Heidegger and Merleau-Ponty. Work presented at Conference Phenomenology and Practical Life. Memphis, USA. Abstract retrieved from https://www.memphis.edu/philosophy/opo2019/pdfs/erciyes-erdem.pdf

Gardner, S. \& Grist, M. (2015). The Transcendental Turn. Oxford, United Kingdom: Oxford University Press. 
Greene, M. (2004). The Progressive Housing Program in Chile 1990 - 2002. Washington, D.C. United States: Inter-American Development Bank.

Greene, M. \& Rojas, E. (2008). Incremental Construction: A Strategy to Facilitate Access to Housing. Environment and Urbanization, 20, 89-108. DOI: https://doi.org/10.1177/0956247808089150

Harms, H. (1982). Historical Perspectives on the Practice and Policies of Self-help Housing. In Ward, P. (Ed.) Self-help Housing: A Critique. London, United Kingdom: Mansell.

Harris, R. (1999). Slipping through the Cracks: The Origins of Aided Self-help Housing, 1918-53. Housing Studies, 14(3), 281-309. DOI: https://doi.org/10.1080/02673039982803

Hasan, A. (2000). Housing for the poor: Failure of formal sector strategies. Johannesburg, South Africa: City Press.

Heidegger, M. (1957). The Principle of Identity. In Heidegger, M. Identity and Difference. (pp. 23-41). Chicago, United States: University of Chicago Press.

Heidegger, M. (1962). Being and Time. New York, United States: Harper.

Heidegger, M. (1971a). Building Dwelling Thinking. In Poetry, Language, Thought. (pp. 155-6). New York, United States: Harper \& Row.

Heidegger, M. (1971b). Poetically Man Dwells ... In Heidegger, M. Poetry, Language, Thought. (pp. 21129). New York, United States: Harper \& Row.

Heidegger, M. (1971c). The Thing. In Heidegger, M. Poetry, Language, Thought. (pp. 163-86). New York, United States: Harper \& Row.

Heidegger, M. (1993). Basic Writings. San Fransisco, United States: Harper.

Heidegger, M. (1994). Basic Questions of Philosophy: Selected Problems of Logic. Bloomington, United States: University Press.

Heidegger, M. (2008). Basic Writings. New York, United States: Harper Perennial Modern Classics.

Heinämaa, S. (2015). Anonymity and Personhood: Merleau-Ponty's Account of the Subject of Perception. Continental Philosophy Review, 48, 123-42. DOI: https://doi.org/10.1007/s11007-015-9329-1

Hill, G. (2008). Adam Sharr, Heidegger for Architects. Architectural Theory Review, 13 (1), 115-118. Kamalipour, H. (2020). Improvising Places: The Fluidity of Space in Informal Settlements. Sustainability, 12(6), 1-14. DOI: https://doi.org/10.3390/su12062293

Lao Tzu. (1955). The Way of Life. New York, United States: New American Library.

Marinovic, G.I. (2020). The Guideline for Customising Incremental Housing Based on Two Chilean Case Studies. Journal of Architecture and Urbanism, 44(2), 166-175. DOI: https://doi.org/10.3846/jau.2020.12056

Marinovic, G.I. (2018). Participatory Sustainability beyond Techno-Aestheticism and Ecological Modernization. Serbia Architectural Journal, 10 (3), 183-200.

ACE, 16 (4.6) CC BY-ND 3.0 ES | UPC Barcelona, España | Belonging to Place: Interpretative Phenomenological Analysis 12 of Incremental Housing. DOI: http://dx.doi.org/10.1080/ace.16.46.9706 
Mària, M. \& Fuertes, P. (2020). About Inhabiting: Subjects, Objects and Habitable Space. ACE: Architecture, City and Environment, 15(44), 9054. DOI: http://dx.doi.org/10.5821/ace.15.44.9054

Moullier, T. \& Krimgold, F. (2015). Building regulation for resilience: managing risks for safer cities. Washington, D.C., United States: World Bank Group.

Mora, R., Greene, M., Gaspar, R. \& Moran, P. (2020). Exploring the mutual adaptive process of homemaking and incremental upgrades in the context of Chile's Progressive Housing Programme (19942016). Journal of Housing and the Built Environment, 35(1), 243-264. DOI: https://doi.org/10.1007/s10901-019-09677-9

Noorloos, V.F., Cirolia, L.R., Friendly, A., Jukur, S., Schramm, S., Steel, G. \& Valenzuela, L. (2019). Incremental housing as a node for intersecting flows of city-making: rethinking the housing shortage in the global South. Environment and Urbanism, 32 (1), 37-54. DOI: https://doi.org/10.1177/0956247819887679

O'Brien, D., Carrasco, S. \& Dovey, K. (2020). Incremental housing: harnessing informality at Villa Verde. Archnet-IJAR: International Journal of Architectural Research, 14(3), 345-358. DOI: https://doi.org/10.1108/ARCH-10-2019-0237

O'Brien, D., \& Carrasco, S. (2021). Incremental housing in Villa Verde, Chile: A view through the Sendai Framework lens. In Martins, N.A., Fayazi, M., Kikano, F., Hobeica, L. (Ed.), Enhancing Disaster Preparedness: From Humanitarian Architecture to Community Resilience (pp. 223-240). Amsterdam, Netherlands: Elsevier.

Okrent, M. (1991). Heidegger's Pragmatism: Understanding, Being, and the Critique of Metaphysics. Ithaca, United States: Cornell University Press.

Ostrom, E. (1990). Governing the commons: The evolution of institutions for collective action. Cambridge, United Kingdom: Cambridge University Press.

Overgaard, S. (2004). Husserl and Heidegger on Being in the World. Dordrecht, Netherlands: Kluwer.

Pandelaki, E. \& Shiozaki, Y. (2010). The Core House Concept and its Implementation in Indonesia: Past, Present, Future. International Journal for Housing Science, 34, 233-248. Recuperado de http://www.housingscience.org/html/publications/pdf/34-4-2.pdf

Perucich, F.V. \& Boano, C. (2016). Bajo escasez ¿Media casa basta? Reflexiones sobre el Pritzker de Alejandro Aravena. Revista de Arquitectura, 21(31), 37-46. DOI: http://dx.doi.org/10.5354/0719$\underline{5427.2016 .42516}$

Pojani, D. (2019). The self-built city: theorizing urban design of informal settlements. Archnet-IJAR: International Journal of Architectural Research, 13(2), 294-313. DOI: https://doi.org/10.1108/ARCH-11$\underline{2018-0004}$

Ruonavaara, H. (2018). Theory of Housing, From Housing, About Housing. Housing, Theory and Society, 35, 178-192. DOI: https://doi.org/10.1080/14036096.2017.1347103

Seamon, D. (2018). Life takes Place; Phenomenology, lifeworlds and place making. Abingdon, United Kingdom: Routledge.

ACE, 16 (46) CC BY-ND 3.0 ES | UPC Barcelona, España | Belonging to Place: Interpretative Phenomenological Analysis 
Sharr, A. (2007). Heidegger for Architects. Abingdon, United Kingdom: Routledge.

The Ministry of Housing and Urban Development. (2020). FSV. Retrieved from www.minvu.cl/busqueda/? wpnonce=3943c6a1a4\& wp http referer=\%2Fopensite 20120504121302. aspx\&texto=FSV

Turner, J. \& Fichter, R. (1972). Freedom to Build, Dweller Control of the Housing Process. Stuttgart, Germany: Collier Macmillan.

Turner, J. (2018). Autoconstrucción por una autonomía del habitar: Escritos sobre vivienda urbanismo autogestión y holismo. La Rioja, España: Pepitas de Calabaza.

Unwin, S. (2009). Analysing architecture. Abingdon, United Kingdom: Routledge.

Valencia, N. (January 18, 2016). Three years in Villa Verde, Elemental's incremental housing project in Constitución, Chile. ArchDaily. Retrieved from: https://www.archdaily.com/780544/three-yearsinvilla-verde-elementals-incremental-housing-project-in-constitucion-chile

Wainer, L., Ndengeyingoma, B., \& Murray, S. (2016). Incremental Housing and Other Design Principles for Low-Cost Housing. International Growth Center (IGC). London, United Kingdom: London School of Economic and Political Science.

Zahavi, D. (2018). Husserl, Heidegger, and Merleau-Ponty on The World of Experience. Oxford Handbook of the History of Phenomenology. Oxford, United Kingdom: Oxford University Press.

Zilliacus, A. (October 24, 2016). Half A House Builds a Whole Community: Elemental's Controversial Social Housing. ArchDaily. Retrieved from: www.archdaily.com/797779/half-a-house-builds-a-wholecommunity

ACE, 16 (46) CC BY-ND 3.0 ES | UPC Barcelona, España | Belonging to Place: Interpretative Phenomenological Analysi 